\title{
The effect of water pre-treatment with poly-aluminium chloride on the decomposition of dissolved organic matter in managed aquifer recharge
}

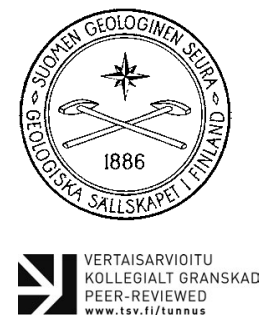

\author{
Paula Nimnikoski-Fußwinkel ${ }^{\mathrm{I}, 2 *}$, Lotta Purkamo ${ }^{3}$ and \\ JUHA KARHU ${ }^{2}$ \\ ${ }^{1}$ Institute of Applied Mineralogy and Economic Geology, RWTH Aachen University, \\ Germany \\ ${ }^{2}$ Department of Geosciences and Geography, University of Helsinki, Finland \\ ${ }^{3}$ Geological Survey of Finland (GTK), Espoo, Finland
}

\begin{abstract}
This study examines the effect of poly-aluminium chloride (PACl) pre-treatment on the biological purification process taking place during managed aquifer recharge (MAR). $\mathrm{PACl}$ treatment is used in waste and surface water treatment to remove organic material. $\mathrm{PACl}$ can decrease the organic carbon contents of water significantly. However, aluminium is toxic to microbes, which may be detrimental when the PACl treatment is followed by infiltration into an aquifer (MAR). In this study the effect of pre-treatment with $\mathrm{PACl}$ on the water purification process in MAR was examined, by using sediment from a MAR site in four test columns. Two columns were filled with PACl-treated water, and the remaining ones with river water without $\mathrm{PACl}$. The residence time of water in the columns was raised from direct sampling gradually to 64 days. Among the parameters monitored were the $\mathrm{pH}$ of the water, microbial activity and the decomposition of dissolved organic carbon (DOC). The results showed active decomposition in all columns. Decomposition of organic matter, and the amount of living/active microbial cells, was marginally higher in the untreated water, which could imply a better functioning MAR system. However, this may also be due to higher DOC starting concentration.
\end{abstract}

Keywords: $\mathrm{PACl}, \mathrm{DOC}$, carbon isotopes, water purification, managed aquifer recharge, isotope hydrology

*corresponding author (email: paula.niinikoski-fusswinkel@emr.rwth-aachen.de)

Editorial handling: Antti Ojala (email: antti.ojala@gtk.fi) 


\section{Introduction}

Poly-aluminium chloride (PACl) is used in water purification to remove organic matter. It is commonly used in waste water treatment, and in purifying surface water (Volk et al., 2000; Duan and Gregory, 2003; Yan et al., 2008; Matilainen et al., 2010; Niinikoski et al., 2016). PACl facilitates the precipitation of dissolved organic carbon (DOC) (Volk et al., 2000; Duan and Gregory, 2003; Yan et al., 2008; Matilainen et al., 2010; Niinikoski et al., 2016). The precipitate can be collected by flotation or sedimentation. After the $\mathrm{PACl}$ treatment other purification methods can be used, one of which is infiltration into suitable soil for further purification. This process is called managed aquifer recharge (MAR) and it is used in water purification for drinking water purposes to further remove DOC (Vartiainen et al., 1987; Sundlöf and Kronqvist, 1992; Hatva, 1996; Grünheid et al., 2005; Kortelainen and Karhu, 2006; Niinikoski et al., 2016).

MAR is especially effective in removing organic contaminants from the surface water (Kortelainen and Karhu, 2006; Kolehmainen et al., 2009; Niinikoski et al. 2016;). The purification process may include adsorption on mineral surfaces, as well as microbial oxidative decomposition, where organic carbon compounds are oxidized into harmless inorganic forms (Vartiainen et al., 1987; Sundlöf and Kronqvist, 1992; Hatva, 1996; Grünheid et al., 2005; Kortelainen and Karhu, 2006; Niinikoski et al., 2016). The latter process relies on non-harmful microbes within the water and the soil, which use organic carbon as their energy source (Kolehmainen et al., 2009; Niinikoski et al., 2016). Normally there is no pre-treatment required in MAR. Surface water is infiltrated into a suitable soil either by pond, bank or well infiltration, or by sprinkling (Vartiainen et al., 1987; Sundlöf and Kronqvist, 1992; Hatva, 1996; Grünheid et al., 2005; Kortelainen and Karhu, 2006; Niinikoski et al., 2016). However, in some special cases pre-treatment may be done to lower the DOC contents of the infiltrated water, to prevent "clogging" the aquifer with organic material absorbed onto mineral surfaces (Niinikoski et al., 2016).

The effect of $\mathrm{PACl}$ on the microbes required for water purification in MAR has not been studied previously. There are two possible pathways by which it can have a negative effect: Firstly, by adding aluminium into the water, and secondly, by removing nitrate. Aluminium is toxic to many microbes (Silver, 1983). Concentrations of less than $50 \mu \mathrm{mol} / \mathrm{L}$ have been found to cause microbes to work less efficiently. The toxicity of aluminium rises with decreasing $\mathrm{pH}$ (Keyser and Munns, 1979; Whelan and Alexander, 1986; Wood et al., 1988; Willey et al., 2009), but it is most mobile in $\mathrm{pH}$ higher than 7.4. Secondly, the $\mathrm{PACl}$ can remove other nutrients besides DOC (Willey et al., 2009). PAC used in effluent treatment may reduce, not only the contents of DOC but also the nitrate contents of the water, which could be vital to efficient microbial decomposition of DOC (Ayysamu et al., 2007; Aghapour et al., 2016). The purpose of this study was to examine, how $\mathrm{PACl}$ treatment affects the decomposition of DOC by microbial activity, by using water and soil from an operational MAR site, Virttaankangas, in southwestern Finland.

Biological processes favour the lighter ${ }^{12} \mathrm{C}$ isotope, which is enriched in organic material (Deines, 1980; Schiff et al., 1997; Vogel, 2012). As DOC is decomposed, it forms inorganic carbon compounds, such as carbonic acid, bicarbonate, carbonate and carbon dioxide (Lindroos et al., 2002; Grünheid et al., 2005; Kortelainen and Karhu, 2006; Kolehmainen et al., 2009). Together these compounds are referred to as dissolved inorganic carbon (DIC). The decomposition process can be monitored by monitoring the isotopic composition of DIC (Kortelainen and Karhu, 2006; Niinikoski et al., 2016). DIC formed from carbonate dissolution or equilibration with atmospheric $\mathrm{CO}_{2}$ has a distinctly heavier isotopic composition than organic carbon. Therefore, as DOC is decomposed to form DIC, it adds lighter carbon into the DIC pool. This change in the 
isotopic composition of DIC can be monitored as an indicator of decomposition of DOC. In this study these compositional changes, as well as other chemical and microbial parameters were used to determine, if $\mathrm{PACl}$ treatment is harmful for the MAR process. The effect of residence times was taken into account by doing experiments with varying durations.

\section{Geological background}

The Virttaankangas esker is a part of the glaciofluvial Säkylänharju-Virttaankangas complex, located in southwestern Finland (Fig. 1). It formed during the late Weichselian and early Holocene deglaciation. The formation is a meltwater deposit between two sublobes of the retreating Baltic Sea ice-lobe (Punkari, 1980; Kujansuu et al., 1995; Mäkinen, 2001) and it can be divided into three units:

1. The lowermost part resulted from repeated deposition of subaqueous fans containing glaciofluvial sands and gravels (Artimo et al., 2003).

2. The intermediate part contains glaciofluvial sand and silt, and associated glaciolacustrine silt and clay deposits of proglacial water body (Artimo et al., 2003).

3. The uppermost $10-20 \mathrm{~m}$ of the complex are littoral sands and gravels formed by the regression of the water level in the Baltic Basin about 11000-10500 years ago (Artimo et al., 2003).

Calcite is present in units 1 . and 2. The concentration is highest in the $<0.2 \mathrm{~mm}$ fraction, $3.7-5$ weight- $\%$, which corresponds to $0.5-1.4$ weight- $\%$ of the total sediment (Artimo et al., 2003). The $\delta^{13} \mathrm{C}$ value of the calcite is $-4.8 \pm 0.5 \%$ (Kortelainen et al., 2007). Calcite dissolution elevates the $\mathrm{pH}$ of natural groundwater to 8-9, with the potential to produce $\mathrm{pH}$ as high as 9.5 (Artimo et al., 2007; Kortelainen and Karhu, 2009). Sediment was collected from layers 2 and 3, from an area not affected by the MAR process, in the non-saturated zone.

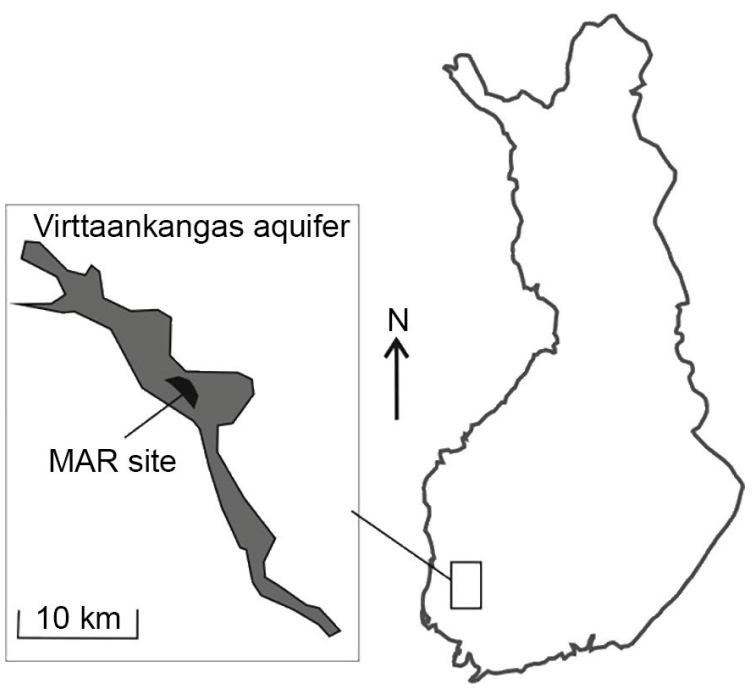

Figure 1. The location of the study area in south-western Finland.

The MAR facility at Virttaankangas was commissioned in 2010. The infiltrated water comes from the Kokemäenjoki River, located $30 \mathrm{~km}$ north from the site (Niinikoski et al. 2016). The infiltrated water volume varies according to demand, in the beginning of production it was $65.000 \mathrm{~m}^{3} /$ day (Niinikoski et al. 2016). The mean residence time of the infiltrated water was estimated by Niinikoski et al. (2016) as varying between 15 and 40 weeks, while travelling distances vary between 300 and $700 \mathrm{~m}$.

\section{Methods}

\subsection{Building the columns}

Black PEH plastic was chosen for the construction of the columns, because, in order to simulate conditions in the esker, light was not allowed to penetrate them. The plastic was tested with pure water to see if it would release carbon into the water, which would interfere with the experiment. The test tube was filled with distilled water, sealed at both ends and allowed to react for three days. After this the water was drained out and the isotopic composition of the DIC it might contain measured. 
Table 1. The different columns and their contents.

\begin{tabular}{|c|cccc|}
\hline Column & A & B & C & D \\
\hline Water type & PAC-treated & riverwater & PAC-treated & riverwater \\
Sediment type & calcite & calcite & no calcite & no calcite \\
\hline
\end{tabular}

The test on the column material showed that there was no measurable DIC leaching from the PEH plastic.

After the experiment four columns were built using pipe made of the same PEH plastic. The columns were $200 \mathrm{~cm}$ high and the diameter was $20 \mathrm{~cm}$. At the bottom an approximately $25 \mathrm{~cm}$ layer of gravel was placed to facilitate the water flow from the tap placed at $20 \mathrm{~cm}$ height. On top of the gravel a metallic sieve was placed, before placing in the sediments. Water was introduced with a hose from the top of the column.

Two of the columns were filled with Virttaankangas sediment containing calcite (A and B, Table 1 ), and two with the littoral sands from unit 3 known to be calcite free (C and $\mathrm{D}$ in Table 1). One column with each type of sediment was filled with untreated river water from the Kokemäenjoki River ( $\mathrm{B}$ and $\mathrm{D}$ in Table 1 ), and the remaining two with the $\mathrm{PACl}$ treated water (A and $\mathrm{C}$ in Table 1). The water was allowed to react for a period of time before draining the columns and analysing the water, after which the columns were filled again, and the time period increased. With each filling the ingoing water was also analysed for the same parameters. The columns were placed in room temperature. Altogether eight sets of experiments were made, in the first ones the water was run straight through the columns ( 0 days), and in the following ones it was allowed to stand for 1, 2, 4, 8, 16, 32 and 64 days.

\subsection{Chemical and isotopic analyses}

Isotopic composition of DIC, alkalinity, $\mathrm{pH}, \mathrm{DOC}$ contents, dissolved oxygen (DO) and main ions sodium, potassium, magnesium, fluoride, chloride, nitrate, sulphate and phosphate were analysed, and temperature was measured. The DOC contents as well as $\mathrm{DO}$ and $\mathrm{pH}$ were measured in the field using an YSI water quality meter equipped with 6562 Rapid Pulse Sensor (dissolved oxygen, precision $\pm 0.2 \mathrm{mg} / \mathrm{L}$, DOC, precision $\pm 1 \mathrm{mg} / \mathrm{L}$ ) and $\mathrm{pH} 6561$ sensor $( \pm 0.2)$. Other parameters were measured at the University of Helsinki, in the Department of Geosciences and Geography. The contents of the main ions were analysed from the samples from 0 residence time to 16 days residence time by Tandem Metrohm Mic12 ion chromatograph (IC). The detection limits for fluoride $(\mathrm{F})$, chloride $(\mathrm{Cl})$ and sulphate $\left(\mathrm{SO}_{4}\right)$ were $0.05 \mathrm{mg} / \mathrm{L}$, for nitrate $\left(\mathrm{NO}_{3}\right)$ $0.1 \mathrm{mg} / \mathrm{L}$, and for sodium $(\mathrm{Na})$, potassium $(\mathrm{K})$, calcium $(\mathrm{Ca})$ and magnesium $(\mathrm{Mg}) 0.08 \mathrm{mg} / \mathrm{L}$. The precision of these analyses was $10 \%$.

Both sediment types were also tested for carbonate. $2 \mathrm{~kg}$ of both sediments were first dried and burned in $700^{\circ} \mathrm{C}$ overnight, in order to remove any organic compound present in the sediment. After burning the $<1 \mathrm{~mm}$ fraction was separated from the samples by sieving. These samples were analysed for carbon by using a CNS Vario Elementar Micro Cube analyser, the precision of which was $10 \%$.

The isotopic composition of DIC was analysed by Isotope-ratio mass spectrometry (IRMS), using a Thermo Finnigan Delta Advantage mass spectrometer, together with laboratory standards, which have been calibrated against an international standard (NBS19). The accuracy for the analysis was $0.1 \%$. The $5 \mathrm{ml}$ samples were injected through $0.8 / 0.2 \mu \mathrm{m}$ Supor membrane syringe filters into helium filled Exetainer tubes, which contained eight drops of $85 \%$ phosphoric acid. The standards were prepared using the same procedure and both were allowed 24 hours to stand in room temperature before analysis. 


\subsection{Microbial analysis}

Samples for cell number and viability analysis were collected from untreated river water and from PACl-treated water. Water samples $(500 \mathrm{ml}$ each) were collected into sterile glass bottles (Schott) and kept cool prior to analysis, in order to minimize biological changes that might take place during transport. Untreated water was visibly brownish and contained some solids. PACl-treated water was clear.

Microbial cells of the water samples were fluorescence-stained with LIVE/DEAD BacLight Bacterial Viability Kit (Thermo Fisher Scientific, MA, USA) according to manufacturer's instructions. Shortly, $15 \mu \mathrm{l}$ of fluorescent dye was mixed with $50 \mathrm{ml}$ of sample water. Mix was incubated in room temperature, protected from light for $15 \mathrm{~min}$. Stained samples were concentrated on black $0.2 \mu \mathrm{m}$ pore-size polycarbonate membrane filters (IsoporeTM Membrane filters, $0.2 \mu \mathrm{m}$ GTBP, Millipore, Danvers, MA, USA) with a Millipore 1225 Sampling Manifold (Millipore, Danvers, MA, USA) using low vacuum suction. The filters were examined under UV light and an epifluorescence microscope at $100 \times$ magnification. Cells were counted in the field of view at 20 randomly chosen locations on the filter. The number of cells in the samples was calculated, on the basis of magnification factor, filtered sample volume, and the active surface area of the filter and the area of the imaging device. Cells with intact cell membranes emitting green fluorescence were considered alive. Red cells were considered nonviable as the cell membranes of these were damaged and were not able to remove the red dye from the interior of the cell.

\subsection{Calculation}

The isotopic composition of water is viewed with $\delta$ values, which are calculated from isotope ratios (the heavier isotope against the lighter one):

$$
\delta_{\text {sample }}=\mathrm{R}_{\text {sample }} / \mathrm{R}_{\text {std }}-1
$$

Where $\mathrm{R}_{\text {sample }}$ is the isotope ratio in the sample and $R_{\text {std }}$ is the same isotope ratio in a standard. For carbon the standard used here is Vienna PeeDee Belemnite (VPDB) (Dansgaard, 1964; Coplen, 2011).

Mass balance is used to calculate fractions ( $\mathrm{f}$ and 1-f) of two components (A and B) in a mix:

$$
f \times \delta_{A}+(1-f) \times \delta_{B}=\delta_{\text {mix }}
$$

Saturation indices and DIC contents were calculated using the PHREEQC geochemical modelling program (Parkhurst and Appelo, 2013).

\section{Results and discussion}

The results of the analyses and modelling are given in Table 2 and in the electronic appendix A.

\subsection{Carbon contents}

The amount of carbon in the calcite-free sediment was 0.14 weight- $\%$ and 0.93 weight- $\%$ in the calcite containing sediment. The fraction of remaining DOC relative to that in input water decreased with increased residence time (Fig. 2), as did the $\delta^{13} \mathrm{C}_{\text {DIC }}$ values (Fig. 3), whereas the calculated contents of DIC increased (Fig. 4). These are clear indicators of DOC decomposition in the columns (Kortelainen and Karhu, 2006; Niinikoski et al., 2016). The change in DIC isotopic composition (Fig. 3) mirrors the changes perceived in MAR facilities, with a steep decline in $\delta^{13} \mathrm{C}_{\text {DIC }}$ values taking place early on and afterwards levelling down (Kortelainen and Karhu, 2006; Niinikoski et al., 2016). Similar trends, although less pronounced can be seen in the changes in DOC and DIC contents (Figs. 2 and 4).

The longest monitored time period was approximately two months, which is significantly shorter than the mean residence times of artificially recharged water in the aquifer at Virttaankangas (Niinikoski et al., 2016). According to the isotopic composition of DIC, there is no difference between the amount of DOC decomposition between the 
Table 2. Selected analysis and modelling results (all results can be found in the appendix).

\begin{tabular}{|c|c|c|c|c|c|c|c|c|c|c|c|c|c|}
\hline Type & Res. Time & Alk & DIC & \multirow[t]{2}{*}{$\mathrm{pH}$} & $\mathrm{Ca}$ & $\mathrm{F}$ & $\mathrm{Cl}$ & $\mathrm{NO}_{3}$ & DOC & $\mathrm{O}_{2}$ & \multirow{2}{*}{$\frac{\delta^{13} \mathrm{C}}{\% \circ \text { VPDB }}$} & \multirow[t]{2}{*}{$\mathrm{SI}_{\mathrm{CaCO} 3}$} & \multirow[t]{2}{*}{$\mathrm{SI}_{\mathrm{CaF} 2}$} \\
\hline & Days & \multicolumn{2}{|c|}{$\mathrm{mmol} / \mathrm{L}$} & & \multicolumn{6}{|c|}{$\mathrm{mg} / \mathrm{L}$} & & & \\
\hline $\mathrm{RW}$ & 0 & 0,26 & 0,29 & 7,3 & 6,71 & 0,15 & 4,44 & 0,87 & 7,6 & 8,1 & $-9,53$ & $-2,00$ & $-3,49$ \\
\hline $\mathrm{RW}$ & 0 & 0,26 & 0,30 & 7,1 & 8,15 & 0,14 & 4,35 & 0,97 & 8,6 & 8,65 & $-9,22$ & $-2,12$ & $-3,47$ \\
\hline RW & 0 & 0,28 & 0,31 & 7,3 & 7,05 & 0,16 & 4,53 & 1,24 & 7,5 & 9,7 & $-9,22$ & $-1,95$ & $-3,41$ \\
\hline RW & 0 & 0,28 & 0,31 & 7,3 & 7,10 & 0,16 & 4,67 & 1,17 & 6,5 & 10,1 & $-9,02$ & $-1,95$ & $-3,41$ \\
\hline RW & 0 & 0,28 & 0,30 & 7,4 & 7,34 & 0,14 & 4,78 & 1,47 & 9,3 & 11,11 & $-7,80$ & $-1,83$ & $-3,52$ \\
\hline RW & 0 & 0,26 & 0,29 & 7,2 & 6,77 & 0,15 & 4,48 & 3,40 & 7,5 & 8,81 & $-9,66$ & $-2,10$ & $-3,49$ \\
\hline PAC & 0 & 0,12 & 0,20 & 6,5 & 6,89 & 0,09 & 11,92 & 1,03 & 3,6 & 9,29 & $-8,84$ & $-3,12$ & $-3,92$ \\
\hline PAC & 0 & 0,12 & 0,17 & 6,7 & 6,78 & 0,06 & 8,76 & 0,72 & 4,0 & 9,37 & $-9,59$ & $-2,92$ & $-4,27$ \\
\hline PAC & 0 & 0,12 & 0,20 & 6,5 & 6,87 & 0,10 & 11,88 & 1,06 & 3,4 & 9,53 & $-9,47$ & $-3,12$ & $-3,83$ \\
\hline PAC & 0 & 0,14 & 0,22 & 6,6 & 7,08 & 0,10 & 12,19 & 1,15 & 2,0 & 11,2 & $-8,55$ & $-2,95$ & $-3,82$ \\
\hline PAC & 0 & 0,14 & 0,19 & 6,8 & 7,23 & 0,07 & 12,37 & 1,27 & 4,4 & 11,89 & $-7,64$ & $-2,74$ & $-4,12$ \\
\hline A & 1 & 0,10 & 0,17 & 6,5 & 8,39 & 0,04 & 11,96 & 0,74 & 3,8 & 8,62 & $-12,88$ & $-3,11$ & $-4,54$ \\
\hline A & 2 & 0,12 & 0,17 & 6,7 & 8,18 & 0,03 & 11,92 & 0,54 & 3,7 & 9,23 & $-13,31$ & $-2,85$ & $-4,80$ \\
\hline A & 4 & 0,11 & 0,17 & 6,6 & 9,63 & 0,04 & 11,92 & 0,39 & 3,5 & 9,06 & $-13,91$ & $-2,92$ & $-4,48$ \\
\hline A & 8 & 0,14 & 0,20 & 6,7 & 8,25 & 0,04 & 11,89 & 0,49 & 2,3 & 8,94 & $-15,71$ & $-2,78$ & $-4,55$ \\
\hline A & 16 & 0,11 & 0,17 & 6,6 & 8,28 & 0,03 & 12,06 & 0,97 & 2,7 & 8,54 & $-16,36$ & $-2,98$ & $-4,79$ \\
\hline A & 32 & 0,15 & 0,20 & 6,8 & 9,07 & 0,02 & 12,20 & 1,26 & 3,0 & 9,72 & $-17,71$ & $-2,61$ & $-5,11$ \\
\hline B & 1 & 0,17 & 0,23 & 6,8 & 6,03 & 0,05 & 4,47 & 0,84 & 5,5 & 8,51 & $-11,80$ & $-2,72$ & $-4,48$ \\
\hline B & 2 & 0,15 & 0,20 & 6,8 & 6,26 & 0,05 & 4,48 & 0,40 & 4,8 & 8,68 & $-12,75$ & $-2,76$ & $-4,46$ \\
\hline$B$ & 4 & 0,17 & 0,26 & 6,6 & 6,54 & 0,05 & 4,45 & 0,43 & 5,4 & 8,53 & $-14,61$ & $-2,89$ & $-4,44$ \\
\hline$B$ & 8 & 0,20 & 0,27 & 6,8 & 6,92 & 0,04 & 4,52 & 0,53 & 2,5 & 8,77 & $-16,44$ & $-2,59$ & $-4,62$ \\
\hline$B$ & 16 & 0,23 & 0,29 & 6,9 & 7,33 & 0,04 & 4,54 & 0,90 & 3,2 & 8,73 & $-17,25$ & $-2,41$ & $-4,59$ \\
\hline$B$ & 32 & 0,28 & 0,31 & 7,3 & 8,32 & 0,03 & 4,65 & 1,14 & 5,0 & 8,64 & $-18,88$ & $-1,87$ & $-4,79$ \\
\hline$C$ & 1 & 0,06 & 0,13 & 6,3 & 6,71 & 0,03 & 11,99 & 0,62 & 2,7 & 8,85 & $-12,07$ & $-3,63$ & $-4,88$ \\
\hline $\mathrm{C}$ & 2 & 0,06 & 0,13 & 6,3 & 6,91 & 0,03 & 11,92 & 0,52 & 2,7 & 9,57 & $-11,77$ & $-3,62$ & $-4,87$ \\
\hline$C$ & 4 & 0,06 & 0,14 & 6,2 & 6,81 & 0,03 & 11,96 & 0,39 & 2,2 & 9,44 & $-12,25$ & $-3,72$ & $-4,88$ \\
\hline C & 8 & 0,07 & 0,13 & 6,4 & 6,67 & 0,03 & 11,90 & $-0,01$ & 2,6 & 8,86 & $-17,50$ & $-3,46$ & $-4,88$ \\
\hline$C$ & 16 & 0,08 & 0,15 & 6,4 & 6,82 & 0,03 & 12,06 & 0,43 & 1,7 & 9,76 & $-18,71$ & $-3,40$ & $-4,88$ \\
\hline C & 32 & 0,10 & 0,15 & 6,6 & 7,41 & 0,01 & 12,21 & 0,62 & 3,1 & 9,9 & $-18,05$ & $-3,07$ & $-5,80$ \\
\hline $\mathrm{D}$ & 1 & 0,28 & 0,52 & 6,4 & 4,45 & 0,03 & 4,48 & 0,92 & 2,7 & 8,52 & $-10,66$ & $-3,04$ & $-5,06$ \\
\hline $\mathrm{D}$ & 2 & 0,08 & 0,14 & 6,5 & 4,43 & 0,03 & 4,49 & 0,90 & 4,0 & 8,71 & $-10,65$ & $-3,48$ & $-5,05$ \\
\hline $\mathrm{D}$ & 4 & 0,09 & 0,17 & 6,4 & 5,71 & 0,04 & 4,48 & 0,60 & 2,4 & 8,93 & $-12,01$ & $-3,42$ & $-4,70$ \\
\hline $\mathrm{D}$ & 8 & 0,15 & 0,22 & 6,7 & 5,22 & 0,04 & 4,49 & 0,89 & 4,9 & 9,22 & $-13,77$ & $-2,94$ & $-4,74$ \\
\hline$D$ & 16 & 0,17 & 0,23 & 6,8 & 5,61 & 0,04 & 4,55 & 1,28 & 5,1 & 8,92 & $-16,04$ & $-2,76$ & $-4,71$ \\
\hline D & 32 & 0,19 & 0,24 & 6,9 & 6,08 & 0,02 & 4,64 & 1,60 & 4,9 & 9,09 & $-17,61$ & $-2,57$ & $-5,28$ \\
\hline
\end{tabular}




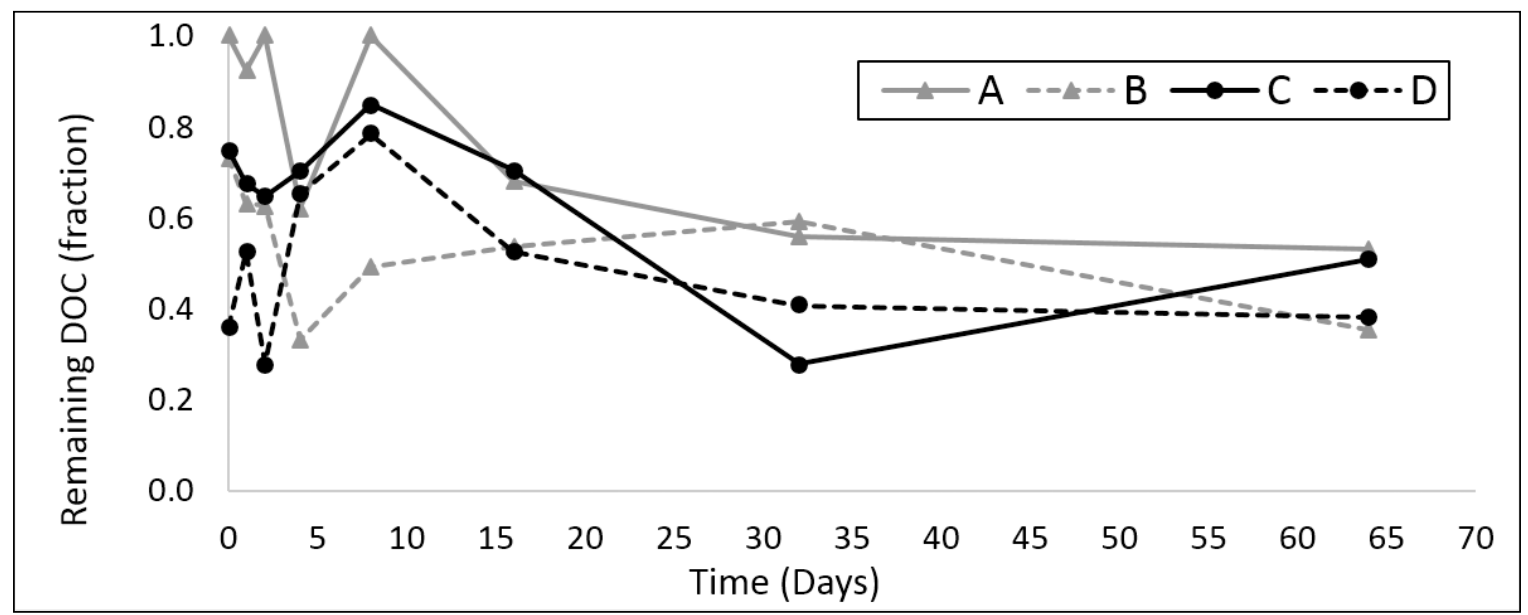

Figure 2. The fraction of dissolved organic carbon (DOC) still remaining in the water as a function of 0-64 days residence time. (A: PACl-treated water with calcite, B: No PACl, with calcite, C: PACl-treated water, no calcite, and D: No PACl and no calcite.)

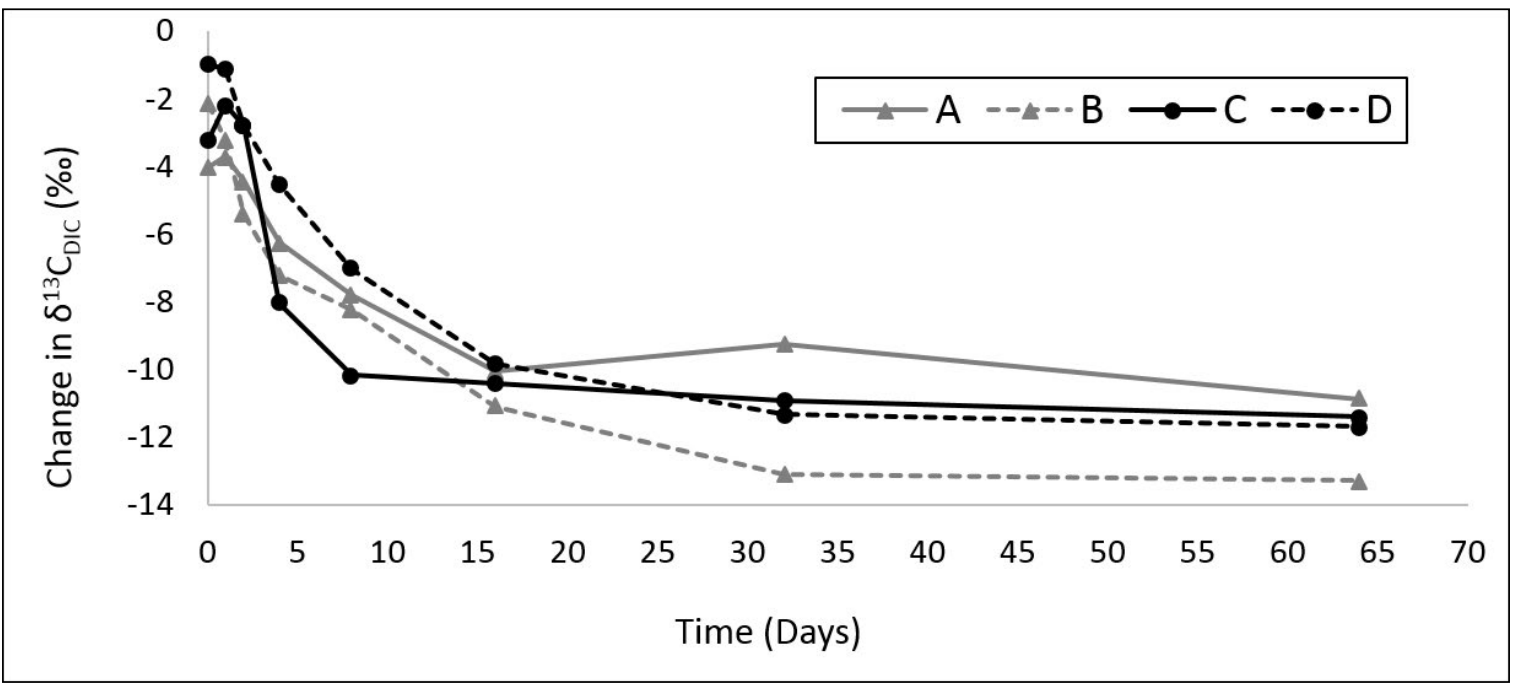

Figure 3. The change in the isotopic composition of dissolved inorganic carbon (DIC) in columns A-D as a function of 0-64 days residence time. (A: PACl-treated water with calcite, B: No PACl, with calcite, C: PACl-treated water, no calcite, and D: No PACl and no calcite.)

32 and 64 day residence times, which implies that residence times longer than one month are not required for adequate $\mathrm{DOC}$ decomposition.

The average starting concentration for DOC in PACl-treated water was $3.5 \mathrm{mg} / \mathrm{L}$, and in non-treated river water $8 \mathrm{mg} / \mathrm{L}$. In the end the DOC concentrations were $2.5 \mathrm{mg} / \mathrm{L}$ and 4 $\mathrm{mg} / \mathrm{L}$, respectively. For pre-treated water this amounted to a $30 \%$ decrease in DOC contents, and for non-pre-treated water the the decrease was $50 \%$. These numbers are within the spectrum found in other studies on DOC decomposition in MAR (Vartiainen et al., 1987; Sundlöf and Kronqvist, 1992; Hatva, 1996; Grünheid et al., 2005; Kortelainen and Karhu, 2006; Niinikoski et al., 2016). Due to the relatively high imprecision of the DOC analysis $( \pm 1 \mathrm{mg} / \mathrm{L})$ compared to the perceived concentration changes, there is a large 


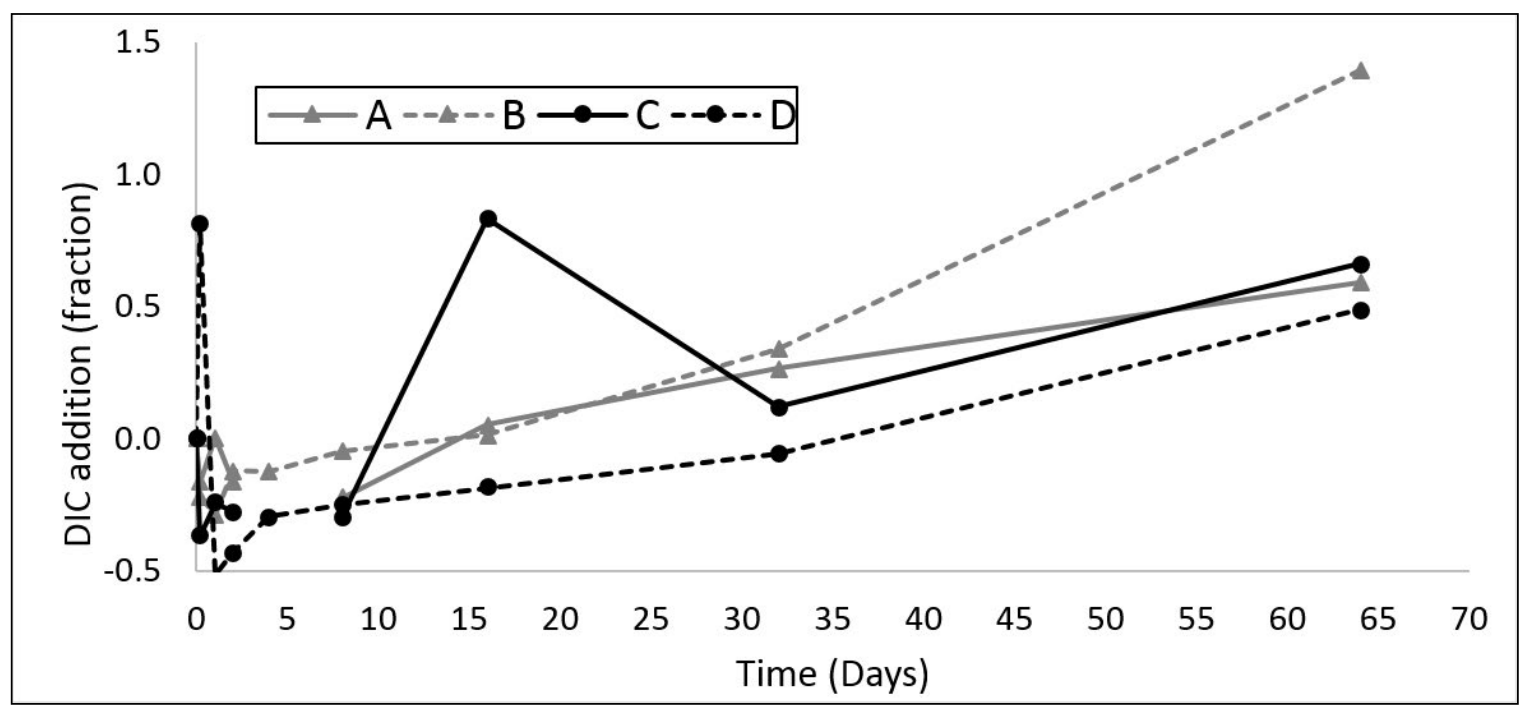

Figure 4. The addition in DIC as a function of residence time in columns A-D, as calculated by PHREEQC. (A: PACltreated water with calcite, B: No PACl, with calcite, C: PACl-treated water, no calcite, and D: No PACl and no calcite.)

inaccuracy involved with these calculations. The isotopic composition of DIC and Equation 2 give approximately $60 \%$ as the amount of DIC which originates in DOC decomposition in the twomonth residence time samples. There are no differences between the two water types.

\subsection{Changes in chemical composition}

The concentration of phosphate was below the detection limit in all samples. The largest chemical difference between the PACl-treated and the river water is chloride concentration, which is between 11.9 and $12.4 \mathrm{mg} / \mathrm{L}$ in $\mathrm{PACl}$-treated water and the water in columns $\mathrm{A}$ and $\mathrm{C}$, and in river water and in columns B and D it is between 4.4 and $4.8 \mathrm{mg} / \mathrm{L}$ (Table 2). The higher chloride contents of $\mathrm{PACl}$-treated water and columns $\mathrm{A}$ and $\mathrm{C}$ reflects the added $\mathrm{PACl}$, and does not play a part in the reactions taking place in the columns.

The contents of nitrate, oxygen and fluoride decrease in all columns. The average concentration of nitrate in the PACl-treated water was $1.1 \mathrm{mg} / \mathrm{L}$, compared to $1.5 \mathrm{mg} / \mathrm{L}$ in the non-treated river water (Table 2). The concentration decreases in all columns, reaching zero in one of the experiments in Column C (PACl-treated water with non-calcite bearing sand). Therefore it is possible, that $\mathrm{PACl}$ that the removal of $\mathrm{NO}_{3}$ from water can create a limiting factor in the functionality of MAR processes.

The decreasing contents of fluoride can be explained by either fluorite $\left(\mathrm{CaF}_{2}\right)$ precipitation, or by microbial activity using fluoride as a nutrient (Marquis et al. 2003; Mukherjee et al., 2017). However, all the samples are undersaturated with fluorite, which makes precipitation unlikely (Table 2). Both dissolved oxygen and fluoride concentrations decrease with increasing residence time (Figs. 5 and 6). DO exhibits a steadier decline (Fig. 5), whereas $\mathrm{F}$ decreases more rapidly in the beginning, and the decline in concentration levels out with increasing residence time (Fig 6). If these changes are the result of microbial activity taking place, the processes removing fluoride would be significantly faster than the processes removing dissolved oxygen.

None of the samples are saturated with calcite, the $\mathrm{SI}_{\mathrm{CaCO} 3}$ being approximately -3 in all of them. This is a clear difference compared to the natural conditions at Virttaankangas, where the natural 


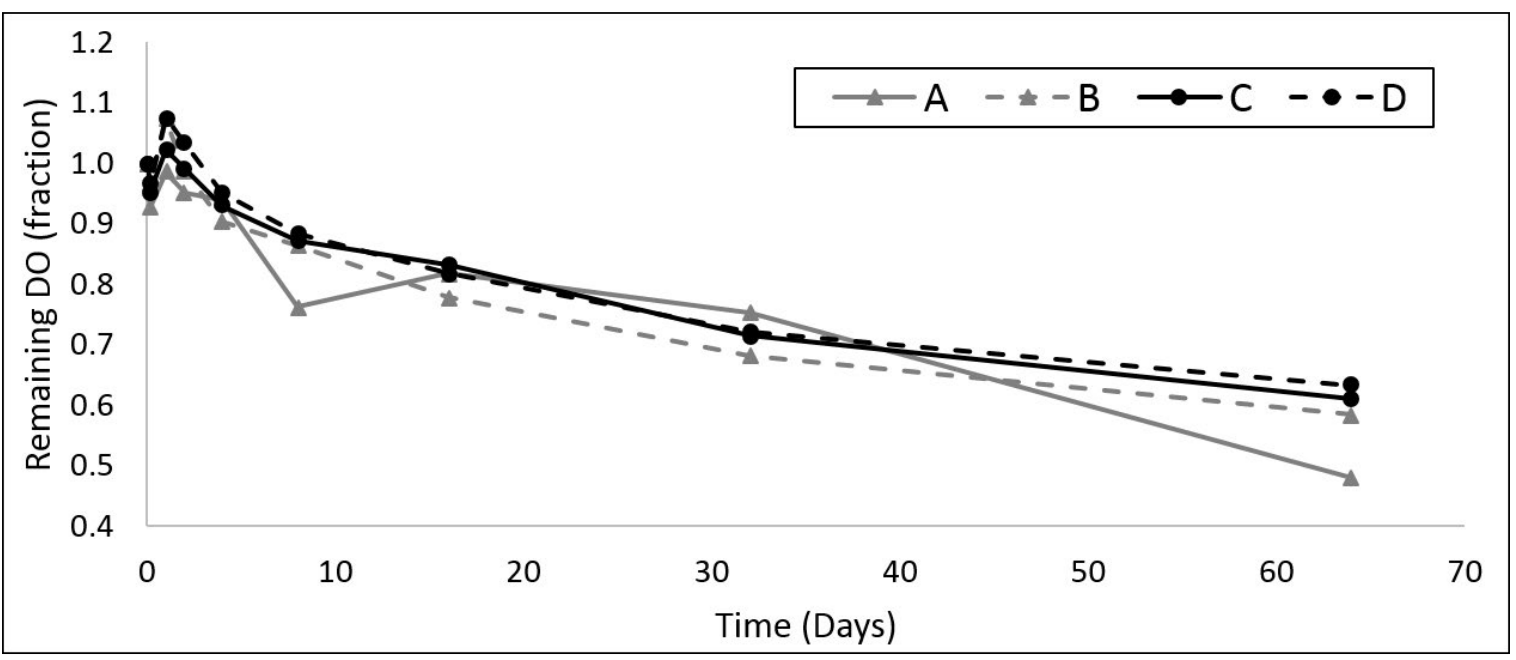

Figure 5. The decrease in dissolved oxygen (DO) contents with increasing residence time in columns A-D, in samples with 0-64 days residence time. (A: PACl-treated water with calcite, B: No PACl, with calcite, C: PACl-treated water, no calcite, and D: No PACl and no calcite.)

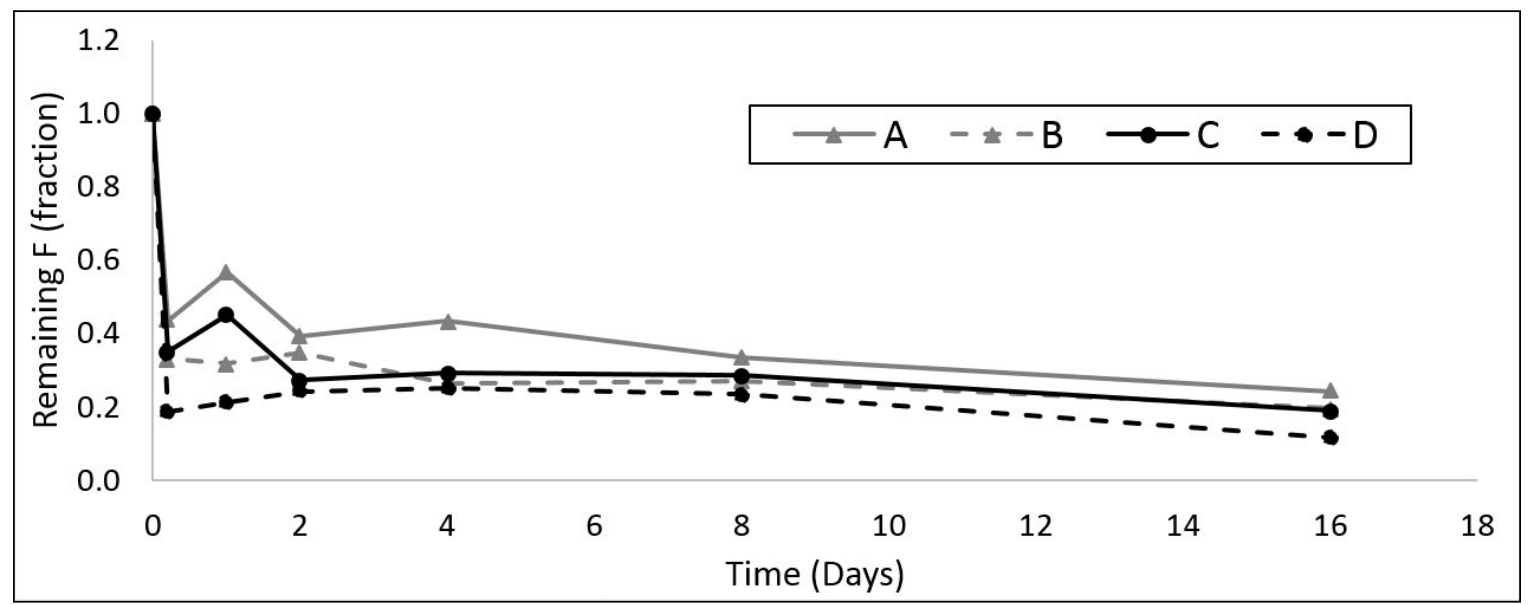

Figure 6. The decrease in fluoride $(F)$ contents with increasing residence time in columns A-D, in samples with 0-16 days residence time. (A: PACl-treated water with calcite, $\mathrm{B}$ : No PACl, with calcite, C: PACl-treated water, no calcite, and D: No PACl and no calcite.)

groundwaters, excepting shallow perched waters, are saturated with calcite (Kortelainen and Karhu, 2009). As a result of calcite dissolution, the $\mathrm{pH}$ of the groundwater has reached values as high as 9 (Kortelainen and Karhu, 2009). The $\mathrm{pH}$ in all of the columns remained close to neutral (Table 2). The carbon contents of the sediment in columns B and $\mathrm{D}$ were higher than in the sediment in columns $\mathrm{A}$ and $\mathrm{C}$, corresponding to the expected carbonate contents in these columns. However, the $\mathrm{SI}_{\mathrm{CaCO} 3}$ remained relatively constant in all columns, which implies that there was little or no calcite dissolution (Table 2). Calcite is relatively slow to dissolve in neutral $\mathrm{pH}$ conditions. In natural conditions, mildly acidic rain water is infiltrated into the esker, where it travels through a layer of soil. In addition, the acidity of soil water in natural conditions is increased by humic acid, further enhancing calcite dissolution. 
Table 3. Microbial cell numbers per $\mathrm{ml}$ of water in untreated river water, and PACl-treated water.

\begin{tabular}{|c|c|c|c|}
\hline Water type & Live & Dead & Total \\
\hline River water & 65500 & 13500 & 79000 \\
\hline PAC-treated water & 58000 & 36000 & 94000 \\
\hline
\end{tabular}

\subsection{Microbial activity}

The treatment of the water with aluminium chloride has a diminishing effect to the amount of living cells in the water (Table 3). Approximately $20 \%$ fewer cells were alive (functional) in the water after the pre-treatment, therefore it is possible that $\mathrm{PACl}$ treatment has an effect on the microbial community in the sediments of the esker. Microbial communities are found to be sensitive to environmental disturbance and changes in community composition may alter ecosystem process rates. However, novel community could be functionally alike to the original and thus, no significant change in ecosystem functioning might not occur (Allison and Martiny, 2008). Therefore, the biological capacity of the surviving microbial community to remove DOC from water cannot be deduced with this analysis.

\section{Conclusions}

There was DOC reduction due to decomposition perceived in all of the columns. A decrease in the contents of DOC was observed in all experimental columns, irrespective of the sediment type or the water pre-treatment. Changes in the DOC contents and the $\delta^{13} \mathrm{C}_{\text {DIC }}$ values as well as the decrease in the number of viable cells in the PACltreated water were some indications that the DOC decomposition process might not work quite as efficiently in the PACl-treated water. The concentration of DOC decreased by $30 \%$ in the pre-treated water, as opposed to $50 \%$ in untreated water, and the microbial community in PACltreated water had fewer viable cells than in the non-treated water. This difference was however countered by the lower starting concentration of DOC in the PACl-treated water, which resulted in lower ending concentration. One month was a long enough time to reach the lowest concentrations, after which the results did not improve further. The isotopic composition of DIC proved that DOC reduction was indeed due to decomposition, and differences in the DOC decomposition effects were minimal between the two types of water. It can be deduced from this study, that the PACl-treatment does not reduce the efficiency of MAR.

\section{Acknowledgements}

This study was funded by K. H. Renlund Foundation. The authors would like to thank Sami Saraperä, Osmo Puurunen, Viivi Sillanpää and Jorma Paavola from the Turku Region Water Ltd. for help in construction and sampling, Nina Hendriksson from the Geological Survey of Finland (GTK) for help in planning the setup of the study, and Hanna Reijola from the University of Helsinki for analysis.

\section{Supplementary Data}

Electronic Appendix A for this article is available via Bulletin of the Geological Society of Finland web page. 


\section{References}

Aghapour, A.A., Nemati, S., Mohammadi, A., Nourmoradi, H. \& Karimzadeh, S., 2016. Nitrate removal from water using alum and ferric chloride: A comparative study of alum and ferric chloride efficiency. Environmental Health Engineering and Management Journal 3(2), 69-73. https://doi.org/10.15171/EHEM.2016.03

Allison, S.D. \& Martiny, J.B.F., 2008. Resistance, resilience, and redundancy in microbial communities. Proceedings of the National Academy of Sciences of the United States of America 105, 11512-11519. https://doi.org/10.1073/pnas.0801925105

Artimo, A., Mäkinen, J., Berg, R.C., Abert, C. C. \& Salonen, V.-P., 2003. Three-dimensional geologic modeling and visualization of the Virttaankangas aquifer, southwestern Finland. Hydrogeology Journal 11(3), 378-386. https://doi.org/10.1007/s10040-003-0256-6Virttaankangas

Artimo, A., Puurunen, O., Saraperä, S. \& Ylander, I., 2007. Geologinen informaatio tekopohjavesihankkeen toteuttamisessa - Pohjavesitutkimukset Virttaankankaalla [Geological information in managed aquifer recharge Groundwater research at Virttaankangas]. Turku Region Waterworks Ltd., Turku, Finland (Report).

Ayysamy, P.M., Shanthi, K., Lakshmanaperumalmasamy, P., Lee, S.-J., Choi, N.-C. \& Kim, D.-J., 2007. Two-stage removal of nitrate from groundwater using biological and chemical treatments. Journal of Bioscience and Bioengineering 104(2), 129-134. https://doi.org/10.1263/jbb.104.129

Coplen, T.B., 2011. Guidelines and recommended terms for expression of stable-isotope-ratio and gas-ratio measurement results. Rapid Communications in Mass Spectrometry 25, 2538-2560. https://doi.org/10.1002/rcm.5129

Dansgaard, W., 1964. Stable isotopes in precipitation. Tellus XVI: 4.

Deines, P., 1980. The Isotopic composition of reduced organic Carbon. In: Fritz, P. \& Fontes, C. (eds.), Handbook of Environmental Isotope Geochemistry vol. 1, Elsevier. Amsterdam, Netherlands, pp. 329-406.

Duan, J. \& Gregory, J., 2003. Coagulation by hydrolysing metal salts. Advances in Colloid and Interface Science 100-102, 475-502. https://doi.org/10.1016/S0001-8686(02)00067-2

Grünheid, S., Amy, G. \& Jekel, M., 2005. Removal of bulk dissolved organic carbon (DOC) and trace organic compounds by bank filtration and artificial recharge. Water Research 39, 3219-3228. https://doi.org/10.1016/j.watres.2005.05.030

Hatva, T., 1996. Artificial groundwater recharge in Finland. In: Kivimäki, A. L. \& Suokko, T., (eds), Proceedings of the Artificial Recharge of Groundwater Symposium, pp. 3-12.
Keyser, H.H. \& Munns, D. N., 1979. Tolerance of rhizobia to acidity, aluminium and phosphate. Soil Science Society of America Journal 43, 519-523. https://doi.org/10.2136/ sssaj 1979.03615995004300030018x

Kolehmainen, R.E., Korpela, J.P., Münster, U., Puhakka, J.A. \& Tuovinen, O.H., 2009. Extracellular enzyme activities and nutrient availability during artificial groundwater recharge. Water Research 43, 405-416. https://doi.org/10.1016/j.watres.2008.10.048

Kortelainen, N.M. \& Karhu, J.A., 2006. Tracing the decomposition of dissolved organic carbon in artificial groundwater recharge using carbon isotope ratios. Applied Geochemistry 21, 547-562. https://doi.org/10.1016/j.apgeochem.2006.01.004

Kortelainen, N.M. \& Karhu, J.A., 2009 Geochemical and isotopic evolution of high-pH groundwater in a carbonate-bearing glacigenic aquifer, SW Finland. Hydrology Research 40.1, 19-31. https://doi.org/10.2166/nh.2009.032

Kortelainen, N.M., Korkeakoski, P.J. \& Karhu, J.A., 2007. Origin of calcite in the glacigenic Virttaankangas complex. Bulletin of the Geological Society of Finland 79, 5-15.

Kujansuu, R., Kurkinen, I., Niemelä, J., 1995. Glaciofluvial deposits in Finland. In: Ehlers, J. et al. (eds.), Glacial deposits in north-east Europe, AA Balkema. Rotterdam, Netherlands, pp. 67-75.

Lindroos, A.J., Kitunen, V., Derome J. \& Helmisaari, H.S., 2002. Changes in dissolved organic carbon during artificial recharge of groundwater in a forested esker in Southern Finland. Water Research 36, 4951-4958. https://doi.org/10.1016/s0043-1354(02)00226-9

Marquis, R.E., Clock, S.A. \& Mota-Meira, M., 2003. Fluoride and organic weak acids as modulators of microbial physiology. FEMS Microbiology Reviews 26, 493-510. https://doi.org/10.1111/j.1574-6976.2003.tb00627.x

Matilainen, A., Vepsäläinen, M. \& Sillanpää, M., 2010. Natural organic matter removal by coagulation during drinking water treatment: A review. Advances in Colloid and Interface Science 159, 189-197. https://doi.org/10.1016/j.cis.2010.06.007

Mukherjee, S., Yadav, V., Mondal, M., Banerjee, S. \& Halder, G., 2017. Characterization of a fluoride-resistant bacterium Acinetobacter sp. RH5 towards assessment of its water defluoridation capability. Applied Water Science 7, 1923-1930. https://doi.org/10.1007/s13201-015-0370-3

Mäkinen, J., 2001. Säkylänharjun-Virttaankankaan harjumuodostuman rakenne ja kehitysvaiheet [The structure and development of the Säkylänharju-Virttaankangas esker]. University of Turku, Turku, Finland. 
Niinikoski, P., Saraperä, S., Hendriksson, N.M. \& Karhu, J.A., 2016. Geochemical and flow modelling as tools in monitoring managed aquifer recharge. Applied Geochemistry 74, 33-43. https://doi.org/10.1016/j.apgeochem.2016.09.001

Parkhurst, D.L. \& Appelo, C.A.J., 2013. Description of input and examples for PHREEQC version 3 - a computer program for speciation, batch reaction, one-dimensional transport and inverse geochemical calculations. In: U. S. Geological Survey Techniques and Methods, Book 6, p. 497.

Punkari, M., 1980. The ice lobes of the Scandinavian ice sheet during the deglaciation in Finland. Boreas 9(4), 307-310. https://doi.org/10.1111/j.1502-3885.1980.tb00710.x

Schiff, S., Aravena, R., Trumbore, S., Hinton, M. J., Elgood, R. \& Dillon, P.J., 1997. Export of DOC from forested catchments on the Precambrian Shield of Central Ontario: Clues from 13C and 14C. Biochemistry 36, 43-65. https://doi.org/10.1023/A:1005744131385

Silver, S., 1983. Bacterial interactions with mineral cations and anions: good ions and bad. In: Westbroek, P. \& DeJong, E. W., (eds.), Biomineralization and Biological Metal Accumulation, Springer. Dordrecht, Netherlands, pp. 439-457.

Sundlöf, B. \& Kronqvist, L., 1992. Artificial groundwater recharge evaluation of twenty Swedish plants. VA-Forsk, Sweden.

Vartiainen, T., Liimatainen, A. \& Kauranen, P., 1987. The use of size exclusion columns in determination of the quality and quantity of humus in raw waters and drinking waters.
Science of the Total Environment 62,75-84. https://doi.org/10.1016/0048-9697(87)90484-0

Vogel, J., 2012. Variability of Carbon isotope fractionation during photosynthesis. In: Ehrlinger, J.R., et al. (eds.), Stable Isotopes and Plant Carbon - Water relations, Academic Press. san Diego, California, pp. 29-38.

Volk, C., Bell K, Ibrahim, E., Verges, D., Amy, G. \& Lechevallier, M., 2000. Impact of enhanced and optimized coagulation on removal of organic matter and its biodegradable fraction in drinking water. Water Resrsearch 34, 3247-3257. https://doi.org/10.1016/S0043-1354(00)00033-6

Whelan, A.M. \& Alexander, M., 1986. Effects of low pH and high $\mathrm{Al}, \mathrm{Mn}$ and Fe levels on the survival of Rhizobium trifolii and the nodulation of subterranean clover. Plant and Soil 92, 363-371. https://doi.org/10.1007/BF02372484

Willey, J.M., Sherwood, L.M. \& Woolverton, C.J., 2009. Prescott's Principles of Microbiology, 1st ed, McGrawHill. Boston, Massachusetts, 969 p.

Wood, M., Cooper, J.E. \& Bjourson, A.J., 1988. Response of Lotus rhizobia to acidity and aluminium in liquid culture and in soil. Plant and Soil 107, 227-231. https://doi.org/10.1007/BF02370551

Yan, M., Wang, D., Ni, J., Qu, J., Chow, C.W.K. \& Liu, H., 2008. Mechanism of natural organic matter removal by polyaluminum chloride: Effect of coagulant particle size and hydrolysis kinetics. Water Research 42, 3361-3370. https://doi.org/10.1016/j.watres.2008.04.017 